1979

\title{
The Professionalization of Philosophy
}

Edward A. Purcell Jr.

New York Law School, edward.purcell@nyls.edu

Follow this and additional works at: https://digitalcommons.nyls.edu/fac_other_pubs

Part of the Law and Philosophy Commons

\section{Recommended Citation}

7 Reviews in American History 51 (1979)

This Article is brought to you for free and open access by the Faculty Scholarship at DigitalCommons@NYLS. It has been accepted for inclusion in Other Publications by an authorized administrator of DigitalCommons@NYLS. 


\title{
THE PROFESSIONALIZATION OF PHILOSOPHY
}

\author{
Edward A. Purcell, Jr.
}

Bruce Kuklick. The Rise of American Philosophy: Cambridge, Massachusetts, 1860-1930. New Haven, Conn.: Yale University Press, 1977. xxvii +674 pp. Illustrations, appendixes, notes, essay on sources, and index. $\$ 17.95$.

During the last decade historians have begun to give long and careful attention to the development of the professional academic disciplines which came in the twentieth century to dominate university organization and control much of the life of the mind. These works have frequently exhibited great technical expertise in the fields studied, together with a sensitive awareness of the connections between the changing parameters of intellectual life and their shifting social context. Moreover, they have often shared a view critical, and even quite skeptical, of both the analytic substance and the professional style of the triumphant academic disciplines. In these studies historians seem to be not merely examining newly important subject matter but also trying to reevaluate the liberal-pragmatic-academic tradition of which most of them are a part. To this collection Bruce Kuklick has added an important study of the development of academic philosophy in the United States. "Like most academics," he concludes, describing the situation at mid-century, "philosophers spent their time in administration, in committee work, in placing graduate students, in organizing conferences, and in running the journals. When narrow professionals turned to their scholarship, they thought of their work as a game." His final indictment is even harsher. "For a few, professional philosophy had become a way, not of confronting the problem of existence, but of avoiding it" (p. 572).

The Rise of American Philosophy is a thoughtful and perceptive study of the philosophical work done at Harvard University which dominated the field in America into the twentieth century and remained powerful through the Second World War. Beginning with an outline of that mid-nineteenthcentury orthodoxy composed of unitarianism and Scottish common sense philosophy, Kuklick then traces the reactions of Harvard philosophers to Darwinism and religious skepticism, the creation and debates of the "great department" of the nineties (Josiah Royce, William James, George Santayana, George Herbert Palmer, and Hugo Munsterberg), structural growth and 
transformation in the first dramatic age of university expansion, the rise of academic professionalism, and the evolution of the almost "great" department of the twenties (C. I. Lewis, Ralph Barton Perry, William Ernest Hocking, and Alfred North Whitehead). It is a difficult book, and in some ways an overly narrow one, but its virtues are many. Kuklick has written a lucid and illuminating history of a major intellectual enterprise.

The book's greatest strength is its careful reconstruction of the intellectual questions and answers that Harvard philosophers placed at the center of their concerns, the ways in which they responded to each other's arguments, and the resulting changes and continuities that characterized philosophical doctrine from the 1860 s to the 1930s. While the author is aware of the influence of exogenous factors on the development of discourse, his focus is on the logic of philosophical debate set predominantly in the context of a powerful internal intellectual tradition. Before we can answer "the difficult questions about the connections of thought with society and personality," he maintains, we must first ascertain exactly "what thinkers have said." That methodological premise serves to justify the book's orientation: "we must discuss the twisting and turning of argument in the context of the philosophical tradition in which the philosophers worked and the implicit demands of logical thinking" (pp. xviii, $x$ vii). Despite occasional repetitiveness, the book succeeds admirably in its central goal. Abstruse argument takes on a new vitality; subtle qualifications emerge with renewed clarity; and the working of an institution that approached an actual "intellectual community" reveals itself.

Still, even accepting the book's focus on logical argument within a disciplined intellectual tradition, caveats are necessary. First, the emphasis sometimes seems to imply that the individuals involved were not just philosophizing within the constraints of logical rigor but were personally motivated by wholly "logical" considerations. The hand of abstraction occasionally rests too heavily on the book. Second, it is questionable whether the intellectual tradition of the Harvard philosophers was quite as narrow as the author implies. One would think that they must have been more aware of, and influenced by, such contemporary intellectual forces as Deweyan instrumentalism, quantum mechanics and relativity theory, the expanding social sciences, Freudian psychology, logical positivism, and semantics than Kuklick indicates. Either he has defined that tradition too narrowly, selecting out only "classic" epistemological and metaphysical problems, or he should explicitly score a point, not just for Harvard leadership, but for Harvard provincialism.

Additionally, there remains the fundamental issue of whether in fact we must learn "what thinkers have said" before we can begin to answer the broader questions, or whether, conversely, our perception of what those thinkers were actually saying is too inextricably bound up with our broader 
interpretative conceptions to be so easily disentangled and objectively fixed. One might speculate that Kuklick's emphasis on the neo-Kantian foundations of "Harvard pragmatism," as well as his own conception of historical change, are rooted to a considerable extent, not simply in what those philosophers "have said," but rather in the reinvigorated neo-Kantianism of our time. Pushed further, there may well be a basic contradiction between the author's paradigmatic theory of intellectual change and his "nominalist" rationale for focusing so narrowly on the written arguments of his protagonists.

In his emphasis on the continued and pervasive influence of Kant Kuklick is at his most provocative. "If we examine the case of Harvard," he concludes, "there is a tradition - a concern for a similar set of problems - that goes from Peirce to Lewis and, I believe, to the most important pragmatic analysts of the quarter century after the war, Nelson Goodman and Willard Van Orman Quine" (p. 577). Inspired by a desire to preserve the intellectual possibilities of religious belief in an age committed to the scientific method, and marked by a special interest in the problem of the structure of logical reasoning, "Harvard pragmatism was a form of neo-Kantianism." Its characteristics were

a constructionalist epistemology stressing the changing character of our conceptual schemes; a commitment to a kind of voluntarism; a concern with the nature of possible experience; a distrust of the tradition of phenomenalistic empiricism; a recognition of the importance of logic for philosophy; discomfort with the dichotomy between the conceptual and the empirical; and a refusal to distinguish between questions of knowledge and of value (p. 257).

The general argument that Kant was central to Harvard philosophy, and thereby to much of American academic philosophy well into the twentieth century, is convincing. No longer may Kantianism be seen as a significant influence on only a small number of pure "idealists" or "rationalists" or viewed merely in contrast to an emerging American "empirical" pragmatism. The Rise of American Philosophy has the distinct virtue of adding considerable complexity, subtlety, and depth to the portrait of the history of American philosophy. Surely Kuklick is right, for example, when he warns that "we must not conclude that pragmatism was a first halting but dramatic step toward twentieth century empiricism" (p. 61). It was rather, as he argues, the complex intellectual response of a group of creative individuals to a historically specific set of perceived philosophical problems which bore only an oblique relationship to many later developments. Kuklick's book suggests Perry Miller's New England Mind (2 vols., 1939, 1953) in reverse: setting the philosophers in their complex intellectual context, it portrays them as more "pious" and less "modern" than we have often thought. 
Many of the book's specific judgments will provoke continued debate. Kuklick argues that Kant was a major influence on James's philosophy, which he describes as an "evolutionary Kantianism." Though it is clear that James was indeed influenced by both Kant and Royce, it is questionable whether such a conclusion does justice to the kaleidoscopic figure who has been mistaken for both a behaviorist and a mystic. Still, Kuklick has added a great deal to our understanding of James's development as a technical philosopher and should establish once and for all the extent to which Ralph Barton Perry's interpretation in the Thought and Character of William James (1935) needs serious revision. The linkage of Goodman and Quine to "Harvard pragmatism," which the author only adumbrates in an appendix, cries out for further analysis and suggests that the idea of a "tradition" may have been stretched too far. Conversely, his dismissal of Santayana's well-known essay on the "Genteel Tradition" should, one hopes, stand the test of time.

Beyond its generally excellent analysis of the "twisting and turning of argument," the book sketches in much of its local institutional and personal background. Kuklick emphasizes the immediate university context and discusses, to a lesser extent, some of the "professional" developments that accompanied the rise of academic philosophy. He traces the influence of Presidents Charles W. Eliot and A. Lawrence Lowell on the department, the constraints of financial uncertainty, the role played by institutional rivalries and the quest for academic prestige, the decline of public, moral, and religious concerns among the philosophers, and the rise of the professional academic entrepreneur and bureaucrat for whom philosophy was largely a "job." The author sees the resulting changes as understandable and perhaps even unavoidable, but, nonetheless, he is not happy with them.

Even with this discussion of local institutional factors, the book is still at times unsatisfying: the focus remains too narrow and broader themes are treated too cryptically. While the Harvard department was clearly preeminent well into the twentieth century, a discussion of developments at other universities - especially Chicago and Columbia - would have been useful. The influence of European ideas is treated only briefly, as is the significance of broader intellectual changes within the United States. In discussing Perry's attempt to work out a systematic ethical theory, for example, Kuklick notes that his later work failed to displace the newly dominant emotivist ethics of C. L. Stevenson. "Stevenson had won," the author declares, "and Harvard ethics had ceased to be viable" (p. 515). Such a transition reflected the broadest intellectual, professional, and social changes of the twentieth century, yet the author does little more than acknowledge their presence and hence fails to explain why, in fact, "Harvard ethics" had lost.

Again, there is almost no discussion of general political and social develop- 
ments. The economic transformation of the late nineteenth century is scarcely mentioned, and the political struggles at the turn of the century play no role. To the extent that such absence accurately reflects the awareness and concerns of the Harvard philosophers, it suggests a great deal about their social orientation as well as about their philosophizing. Though social and political matters are not the book's subject, a fuller understanding of "Harvard pragmatism" may well require their examination. A philosophical style, no matter how abstract, has a relationship to the broader society; and, as the author points out, "Harvard pragmatism" developed at precisely the time when "intellectuals" were being incorporated into a burgeoning and powerful institutional matrix. Is it not possible that the absence from the philosophers' concerns of the problems created by industrialization, urbanization, and political reform - at a time when those issues preoccupied much of the society-derived from factors that were as crucial to the style and significance of "Harvard pragmatism"as was the intellectual shadow of Immanuel Kant?

The book comes closest to dealing with such issues in its discussions of President Lowell's relationship to the department and of the philosophers' response to World War I. The former brings out clearly the "social" requirements for a position at the university, and the latter illustrates the political naiveté and bias of the philosophers themselves. Both chapters are illuminating, though each could have been expanded to explore further the social bases of Harvard philosophy. An explanation of the philosophers' extreme propagandistic response to the war, especially in contrast to their near total lack of concern with the political and social turmoil of the preceding three decades, requires more than reference to a lack of knowledge of politics, a general spread of "thoughtless patriotism," a desire to overcome ivory tower isolation, and incorporation into an institution devoted to wartime propaganda. Why, indeed, was their institution so devoted? Rather, such an explanation must probe and delineate the comprehensive social/intellectual framework of the philosophers' thought and values, and that framework in all its fullness of texture may in turn help explain not just the response to the war but also the style and orientation of the resulting philosophy.

Though he does not delve deeply into the implicit values and social foundations of "Harvard pragmatism" itself, the author does outline a major reorientation in the values manifested by academic philosophy as a whole. By the early twentieth century the general interest of philosophers in any basic moral issue of public relevance was falling victim to the new demands of "professionalism." "Amateur" philosophy was in decay, and only a university could provide the kinds of support that enabled a philosopher to receive a serious hearing. The field developed new criteria of achievement; the areas of specialization became increasingly narrow and technical; and 
the "center of attention shifted from philosophy and life to status in (or the status of) 'the profession'" (p.xxii). Finally, Kuklick suggests, when the process of professionalization was completed in the twenties and thirties, "society ceased to be a direct influence in shaping philosophical ideas, and the link between personality and philosophy dissolves" (p. xviii). Hence the profession of philosophy became an autonomous institution at the cost of losing its public role and relevance. The author pictures this development as part of "the decisive transformation in American thought in the twentieth century" (p. 560). That transformation meant rigid intellectual compartmentalization: Whitehead was unable to carry on a dialogue with an educated public; Lewis could not successfully change fields within the profession; and their contempo. raries and successors for the most part did not even wish to attempt either.

While much of this description is both accurate and familiar, the book treats such a major theme far too sketchily. There is a large literature dealing with the social paradoxes of the professional ideal, but the author does not seem to draw on any of it directly. There is little discussion of the changing structure of the profession as a whole. There is scarcely any analysis of the concept of "professionalization" or of exactly what it meant to the philosophers themselves. Nor, again, is there any extended discussion of the general significance of that "decisive transformation" or of the ways in which the changes in philosophy related to similar changes occurring in other fields. To some extent this may be the classic unfair tactic of criticizing an author for the book he did not choose to write, and yet these themes recur throughout the book and certainly lie at the center of its concern. It is to be hoped that in his future work Kuklick will add somewhat greater structural breadth to his analysis of the history of American philosophy.

On the most general level the book raises by implication a number of fundamental questions about professional philosophy and the academic disciplines in general. What, for example, has actually been gained by the "technical advances" in such subfields as logic or epistemology? How does this compare in importance to what academic philosophy has concomitantly lost? What was the structural basis in the nineteenth century of the "educated public" which some philosophers sought to address, and in what ways has this public changed in the twentieth? To what extent is "the demise of the educated public" actually a product of a narrow professionalism determined to guarantee its status by the creation of its own arcanum? Given the nature of twentieth-century society and the continued dominance of the professional academic disciplines, such questions lie at the heart of the problems of recent intellectual history.

Kuklick's book is a significant achievement, and most of the criticisms I have made relate to additional problems that might have been explored 
rather than to inadequacies in what was actually covered. The book carefully and cogently examines a major chapter in the development of American philosophy and speeds the process of integrating a sophisticated analysis of philosophical change into the broader history of American thought. It will become a standard source and, for many years, the measure of work done in the history of American philosophy.

Edward Purcell teaches in the Department of Social Studies, Harvard University, and is the author of "Alexander M. Bickel and the Post-Realist Constitution," Harvard Civil Rights/Civil Liberties Law Review 11 (1976). 